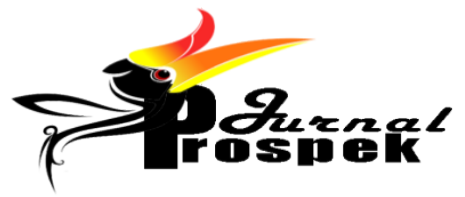

http://e-journals.unmul.ac.id/index.php/jpe

Jurnal Prospek : Pendidikan Ilmu Sosial dan Ekonomi

Volume 3 No 1 Juli 2021

E-ISSN 2721-0855

\title{
ANALISIS KONTRIBUSI PAJAK DAERAH TERHADAP PENDAPATAN ASLI DAERAH (PAD) KOTA SAMARINDA PERIODE $2014-2018$
}

\author{
Muklis Firmansyah \\ Universitas Mulawarman \\ muklisfirmansyah1@gmail.com \\ Kaspul \\ Universitas Mulawarman \\ kaspul@fkip.unmul.ac.id \\ Vitria Puri Rahayu \\ Universitas Mulawarman \\ vitria.puri@fkip.unmul.ac.id
}

\begin{abstract}
This study aims to determine how much the contribution of local taxes to the Regional Original Revenue of Samarinda City in the period 2014 - 2018. This type of research uses quantitative descriptive. Data collection techniques used are secondary data by using the method of documentation and study of literature. The analytical tool used in this study is the ratio of local tax contributions. The results of this study indicate that the local tax element that gives the biggest contribution to the increase in regional income is the street lighting tax with an average contribution over a five-year period of $20.00 \%$. Based on the results of the study it can be concluded that the contribution of regional tax in the period 2014 - 2018 is quite good towards the Original Revenue of Samarinda City.
\end{abstract}

Keywords: local tax, local revenue, contribution

Abstrak: Penelitian ini bertujuan untuk mengetahui seberapa besar kontribusi pajak daerah terhadap Pendapatan Asli Daerah Kota Samarinda pada periode 2014 - 2018. Jenis penelitian ini menggunakan deskriptif kuantitatif. Teknik pengumpulan data yang digunakan yaitu data sekunder dengan mengunkan metode dokumentasi dan studi pustaka. Alat analisis yang digunakan dalam penelitian ini adalah rasio kontribusi pajak daerah. Hasil penelitian ini menunjukkan bahwa elemen pajak daerah yang memberikan kontribusi terbesar terhadap peningkatan pendapatan daerah adalah pajak penerangan jalan dengan rata-rata kontribusi selama periode lima tahun adalah 20,00\%. Berdasarkan hasil penelitian dapat disimpulkan bahwa kontribusi pajak daerah periode 2014 - 2018 cukup baik terhadap Pendapatan Asli Daerah Kota Samarinda.

Kata kunci: pajak daerah, pendapatan asli daerah, kontribusi 


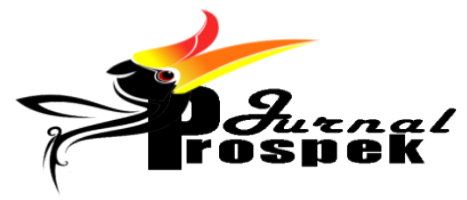

http://e-journals.unmul.ac.id/index.php/jpe

Jurnal Prospek : Pendidikan Ilmu Sosial dan Ekonomi

Volume 3 No 1 Juli 2021

E-ISSN 2721-0855

Dalam era otonomi daerah sekarang ini, daerah diberikan kewenangan yang lebih besar untuk mengatur dan mengurus rumah tangganya sendiri, dengan tujuan antara lain ialah untuk mempercepat terwujudnya kesejahteraan masyarakat dengan lebih mendekatkan pelayanan pemerintah kepada masyarakat, memberdayakan masyarakat dan meningkatkan peran serta masyarakat. Selain itu untuk menciptakan persaingan yang sehat antar daerah dengan memperhatikan prinsip demokrasi, pemerataan, keadilan, keistimewaan dan potensi serta keanekaragaman daerah dalam sistem Negara Kesatuan Republik Indonesia dan mendorong timbulnya inovasi-inovasi yang sesuai dengan kebutuhan masyarakat.

Otonomi daerah dapat dilaksanakan sejalan dengan tujuan yang hendak dicapai, pemerintah daerah harus mampu mengembangkan dan memaksimalkan segala sumber daya yang tersedia guna membiayai penyelenggaraan pemerintah daerah dan pembangunan daerah. Ada banyak sumber pendapatan daerah namun dari berbagai sumber belum semua dimaksimalkan, salah satu upaya yang dilakukan pemerintah daerah adalah dengan meningkatkan Pendapatan Asli Daerah (PAD). Sumber-sumber pendapatan asli daerah yang potensial harus digali secara maksimal sesuai dengan ketentuan dan peraturan yang berlaku, termasuk diantarnya adalah pajak daerah dan retribusi daerah yang menjadi unsur utama PAD.

Undang-Undang No. 12 Tahun 2008 pasal 157 tentang pemerintahan daerah, adapun sumber Pendanaan pelaksanaan Pemerintah Daerah itu sendiri terdiri dari, Pendapatan Asli Daerah, Dana Perimbangan dan Lain-lain Pendapatan yang Sah. Salah satunya PAD, yaitu berupa pajak daerah yang diharapkan dapat menjadi salah satu sumber pembiayaan pemerintah dan pembangunan daerah, untuk meningkatkan dan meratakan kesejahteraan masyarakat. Pendapatan asli daerah adalah penerimaan yang diperoleh dari sektor pajak daerah, retribusi daerah, hasil perusahaan milik daerah, hasil pengeloalaan kekayaan daerah yang dipisahkan, dan lain-lain pendapatan asli daerah yang sah (Mardiasmo, 2011:1).

Pelaksanaan pemungutan setiap jenis pajak dan retribusi akan dipungut oleh tiap-tiap satuan kerja seperti perangkat, badan-badan pemerintahan Kota Samarinda, BUMN, BUMD serta pihak swasta sesuai dengan jenis pajak daerah dan retribusi daerah tersebut. Dari data diatas, kita dapat mengetahui dengan adanya pajak daerah dapat memberikan kontribusi 


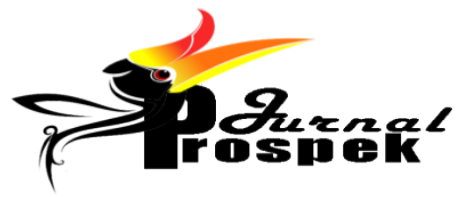

http://e-journals.unmul.ac.id/index.php/jpe

Jurnal Prospek : Pendidikan Ilmu Sosial dan Ekonomi

Volume 3 No 1 Juli 2021

E-ISSN 2721-0855

besar terhadap Pendapatan Asli Daerah (PAD) kota Samarinda, terutama sejak adanya kebijakan otonomi daerah dan didukung dengan kondisi Kota Samarinda yang menjadi Ibu Kota Provinsi. Usaha-usaha untuk menggali sumber-sumber pendapatan daerah, mengalami berbagai kendala, baik dari segi keterbatasan sumber dana maupun dari segi sumber manusia dan sistem pengelolaan serta administrasinya.

Pajak Daerah kabupaten/kota adalah pemungutan dari masyarakat oleh Negara (pemerintah) berdasarkan Undang-Undang yang bersifat dapat dipaksakan dan terhutang oleh wajib pajak membayarnya dengan tidak mendapat prestasi kembali (balas jasa) secara langsung, yang hasilnya digunakan untuk membiayai pengeluaran Negara dalam penyelenggaraan pemerintah dan pembangunan. (Siahaan 2009:7)

Menurut Mardiasmo (2011:4) Pajak Daerah ialah salah satu komponen penyumbang terbesar dalam struktur Pendapatan Asli Daerah (PAD). Dan yang nantinya dari hasil pembayaran Pajak itu sendiri akan dikembalikan kepada masyarakat dalam bentuk pembangunan pada daerah yang dilaksanakan dan digunakan untuk kesejahteraan masyarakat. Pajak daerah itu sendiri terdiri dari Pajak Hotel, Pajak Restoran, Pajak Hiburan, Pajak Reklame, Pajak Penerangan Jalan, Pajak Parkir, Pajak Air Tanah, Pajak Sarang Burung Walet, Pajak Mineral Bukan Logam dan Batuan, Pajak Bumi dan Bangunan Perdesaan dan Perkotaan, Bea Perolehan Hak Atas Tanah dan Bangunan .

Kondisi permasalahan yang ditemui ialah pengelolaan pendapatan daerah tidak sama pada masing-masing daerah, karena menyangkut tersedianya sumber tingkat kemajuan pembangunan serta kemampuan sumber-sumber pendapatan yang ada. Oleh karena itu harus diketahui jumlah pendapatan daerah dari pajak daerah tersebut. Apakah telah mengalami perkembangan yang cukup baik di Samarinda atau malah sebaliknya mengalamin penurunan.

Menurut data Badan Pendapatan Daerah Kota Samarinda di tahun 2016 realisasi pendapatan asli daerah kota Samarinda mengalami peningkatan dari tahun 2012 sebesar 263.902.471.374 dan ditahun 2014 sebesar 435.492.590.745 tetapi pada tahun 2015 sebesar 408.195.248.641 sampai tahun 2016 sebesar 391.478.411.832 mengalami penurunan. Dalam hal ini di kususkan kepada pemerintah kota Samarinda haruslah menggali sumber-sumber pendapatan asli daerah (PAD), yang salah satunya bersumber dari penerimaan pajak daerah. 


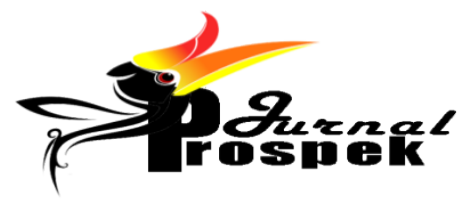

http://e-journals.unmul.ac.id/index.php/jpe

Jurnal Prospek : Pendidikan Ilmu Sosial dan Ekonomi

Volume 3 No 1 Juli 2021

E-ISSN 2721-0855

Untuk membantu kegiatan pengelolaan dan sebagai instansi yang akan membantu dalam pelaksanaan pembangunan daerah kota Samarinda yaitu Badan Pendapatan Kota Samarinda.

Dikarenakan Pajak daerah sangat memberikan kontribusi yang besar terhadap pendapatan asli daerah (PAD), maka dari itu Badan Pendapatan Kota Samarinda sebagai unsur melaksanakan pemerintahan memiliki peran penting dalam menggali sumber-sumber pendapatan yang berupa pajak daerah Samarinda. Dalam hal ini akan terlihat jelas kontribusi pendapatan daerah di sektor Pajak Daerah sangat membantu bagi daerah untuk mengembangkan daerahnya masing-masing agar masyarakatnya hidup sejahtera. Dan melihat efektifitas dalam memungut Pajak Daerah yang dilakukan oleh Badan Pendapatan Kota Samarinda apakah sudah melebihi target yang sudah di rencanakan oleh pemerintah kota Samarinda yang pemungutannya dilakukan oleh Badan Pendapatan Daerah Kota Samarinda. Hasil penelitian tentang pajak daerah terhadap pendapatan asli daerah (PAD) kota samarinda telah di lakukan oleh (Nugroho, 2017), (Utami, 2018) Untuk mengetahui seberapa efektifitasnya dan kontribusi pajak daerah dan retribusi daerah disamarinda.

Berdasarkan uraian diatas maka penulis tertarik melakukan penelitian ini dengan judul “Analisis Kontribusi Pajak Daerah Terhadap Pendapatan Asli Daerah (PAD) Kota Samarinda Periode 2014-2018”. Adapun tujuan penelitian ini yaitu untuk mengetahui kontribusi pajak daerah terhadap PAD Kota Samarinda periode 2014 - 2018.

\section{METODE}

Jenis penelitian ini adalah deskriptif kuantitatif penelitian ini menggunakan data sekunder dengan teknik pengumpulan data menggunakan dokumentasi dan studi pustaka dengan mencatat dan menelusuri data laporan realisasi anggaran, realisasi PAD, dan realisasi pajak daerah Kota Samarinda, mulai tahun 2014 sampai dengan 2018 yang diperoleh dari BAPENDA Kota Samarinda. Selain itu juga peneliti menelusuri sumber data dari website resmi pemerintah daerah Kota Samarinda, website Badan Pusat Statistik Kota Samarinda dan beberapa sumber lainnya yang relevan.

Teknik analisis data yang dilakukan adalah sebagai berikut:

1. Mengumpulkan data realisasi anggaran, realisasi PAD dan realisasi pajak daerah

2. Melakukan perhitungan perkembangan data realisasi setiap tahunnya 


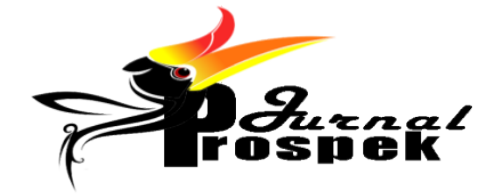

http://e-journals.unmul.ac.id/index.php/jpe

Jurnal Prospek : Pendidikan Ilmu Sosial dan Ekonomi

Volume 3 No 1 Juli 2021

E-ISSN 2721-0855

3. Melakukan analisis rasio kontribusi pajak daerah terhadap PAD

4. Mengklasifikasikan Kriteria Kontribusi Komponen Pajak Daerah

5. Mengambil kesimpulan

\section{HASIL}

\section{Perkembangan Penerimaan Pajak Daerah di Kota Samarinda}

Pajak daerah merupakan sumber penerimaan yang cukup potensial untuk dikembangkan sesuai dengan kondisi masing-masing daerah termasuk di Kota Samarinda. Untuk melihat besar kecilnya penerimaan pajak daerah di Kota Samarinda dari tahun 2014 sampai dengan tahun 2018 dapat dilihat pada tabel berikut ini:

Tabel 1. Realisasi Penerimaan Pajak Daerah Kota Samarinda 2014-2018

\begin{tabular}{lccc}
\hline Tahun & Pajak Daerah (Rp) & $\begin{array}{c}\text { Peningkatan / } \\
\text { Pengurangan (Rp) }\end{array}$ & Presentase (\%) \\
\hline 2014 & $238.511 .683 .138,63$ & & $106,05 \%$ \\
\hline 2015 & $244.079 .216 .597,34$ & $5.567 .533 .458,71$ & $94,66 \%$ \\
\hline 2016 & $256.130 .052 .909,60$ & $12.050 .836 .312,26$ & $88,17 \%$ \\
\hline 2017 & $298.807 .221 .123,93$ & $42.677 .168 .214,33$ & 113,71 \\
\hline & & & \\
\hline
\end{tabular}

Sumber: Badan Pendapatan Daerah Kota Samarinda (2019)

Berdasarkan Tabel 1 di atas dapat dilihat bahwa telah terjadi peningkatan penerimaan pajak daerah setiap tahunnya mulai tahun 2014 sampai 2018. Peningkatan dalam sisi jumlah penerimaan terjadi paling tinggi yaitu dari tahun 2017 ke tahun 2018 sejumlah Rp 54.228.680.625,51, pada sisi persentase pajak daerah terjadi paling tinggi pada tahun 2017 dan 2018 yaitu sebesar 113,89\%.

\section{Perkembangan Penerimaan PAD Kota Samarinda}

Kemandirian pemerintah kabupaten/kota dapat dilihat dari besarnya PAD yang diperoleh pemerintah kabupaten/kota tersebut, semakin besar PAD yang diperoleh oleh pemerintah kabupaten/kota, maka akan semakin mengurangi ketergantungan pemerintah daerah terhadap bantuan dari pemerintah pusat, begitu juga di Kota Samarinda. Untuk mengetahui 


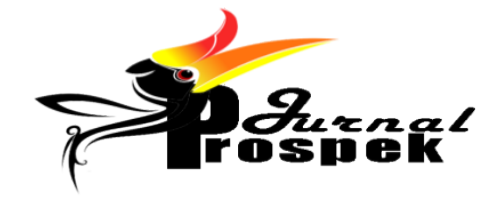

http://e-journals.unmul.ac.id/index.php/jpe Jurnal Prospek : Pendidikan Ilmu Sosial dan Ekonomi

Volume 3 No 1 Juli 2021

E-ISSN 2721-0855

jumlah penerimaan dan perkembangan PAD di Kota Samarinda dapat dilihat pada tabel 2 berikut ini:

Tabel 2. Realisasi Perkembangan PAD Kota Samarinda Tahun 2014-2018

\begin{tabular}{cccc}
\hline Tahun & Hasil Perhitungan & $\begin{array}{c}\text { Peningkatan / } \\
\text { Pengurangan \% }\end{array}$ & Persentase(\%) \\
\hline 2014 & $435.492 .590 .745,66$ & & $75,40 \%$ \\
\hline 2015 & $408.195 .248 .641,01$ & $27.297 .342 .104,65$ & $49,81 \%$ \\
\hline 2016 & $391.478 .411 .832,07$ & $16.716 .836 .808,94$ & $83,40 \%$ \\
\hline 2017 & $517.499 .223 .222,34$ & $126.020 .811 .390,27$ & $102,02 \%$ \\
\hline 2018 & $499.229 .231 .885,96$ & $18.269 .991 .336,38$ & $112.10 \%$ \\
\hline
\end{tabular}

Sumber: Badan Pendapatan Daerah Kota Samarinda (data diolah: 2019)

Berdasarkan Tabel 2 di atas dapat di lihat bahwa telah terjadi peningkatan penerimaan PAD mulai tahun 2014 sampai 2018. Peningkatan dalam sisi jumlah penerimaan terjadi paling tinggi yaitu tahun 2016 ke tahun 2017 sejumlah Rp 126.020.811.390,27, namun pada sisi persentase Pendapatan Asli Daerah terjadi paling tinggi pada tahun 2018 yaitu sebesar $112,10 \%$

\section{Kontribusi Pajak Daerah Terhadap PAD Kota Samarinda}

Pajak daerah adalah salah satu komponen dari PAD dan digunakan untuk membiayai pengeluaran dalam melaksanakan wewenang dan tanggung jawabnya kepada masyarakat. Untuk melihat besarnya kontribusi pajak daerah terhadap PAD dapat dilihat pada tabel 3 di bawah ini. 


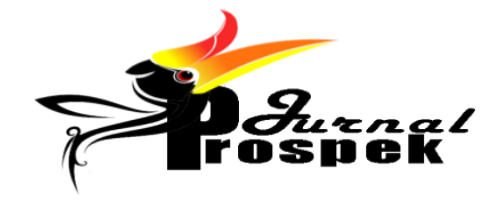

http://e-journals.unmul.ac.id/index.php/jpe Jurnal Prospek : Pendidikan Ilmu Sosial dan Ekonomi

Volume 3 No 1 Juli 2021

E-ISSN 2721-0855

Tabel 3. Kontribusi Pajak Daerah Terhadap Pendapatan Asli Daerah

\begin{tabular}{cccc}
\hline Tahun & $\begin{array}{c}\text { Realisasi Pajak Daerah } \\
\text { (Rp) }\end{array}$ & $\begin{array}{c}\text { Realisasi } \\
\text { PAD (Rp) }\end{array}$ & $\begin{array}{c}\text { Kontribusi Pajak } \\
\text { Daerah } \\
\text { Terhadap PAD } \\
\text { (\%) }\end{array}$ \\
\hline 2014 & $238.511 .683 .138,63$ & $435.492 .590 .745,66$ & $54,77 \%$ \\
\hline 2015 & $244.079 .216 .597,34$ & $408.195 .248 .641,01$ & $59,79 \%$ \\
\hline 2016 & $256.130 .052 .909,60$ & $391.478 .411 .832,07$ & $65,43 \%$ \\
\hline 2017 & $298.807 .221 .123,93$ & $517.499 .223 .222,34$ & $57,74 \%$ \\
\hline 2018 & $353.035 .901 .749,44$ & $499.229 .231 .885,96$ & $70,72 \%$ \\
\hline
\end{tabular}

Sumber: Data diolah (2019)

Berdasarkan Tabel 3 tersebut dapat dilihat bahwa mulai tahun 2014 hingga tahun 2018 persentase kontribusi realisasi pajak daerah terhadap realisasi PAD mengalami kenaikan yang sangat signifikan. Secara rata-rata selama 5 tahun, realisasi pajak daerah memberikan kontribusi “sangat baik” terhadap realisasi penerimaan PAD sebesar 61,69\%.

\section{Kontribusi Komponen PAD Terhadap Pendapatan Asli Daerah}

Komponen PAD terdiri atas 4 komponen yaitu pajak daerah, retribusi daerah, hasil pengelolaan kekayaan daerah yang dipisahkan dan lain-lain PAD yang sah. Besar atau kecilnya kontribusi realisasi pajak daerah terhadap realisasi PAD, akan sangat ditentukan pula oleh realisiasi penerimaan retribusi daerah, hasil pengelolaan kekayaan daerah yang dipisahkan dan lain-lain PAD yang sah.

Tabel di bawah ini menyajikan kontribusi masing-masing realisasi komponenkomponen PAD terhadap realisasi PAD mulai tahun 2014 hingga tahun 2018. 


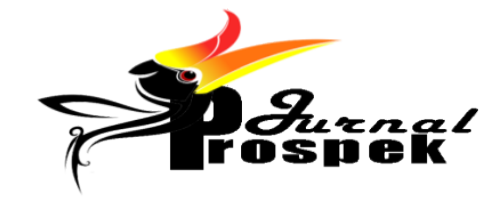

http://e-journals.unmul.ac.id/index.php/jpe Jurnal Prospek : Pendidikan Ilmu Sosial dan Ekonomi

Volume 3 No 1 Juli 2021

E-ISSN 2721-0855

Tabel 4. Kontribusi Realisasi Komponen PAD terhadap Realisasi PAD.

\begin{tabular}{ccccc}
\hline Tahun & $\begin{array}{c}\text { Pajak } \\
\text { Daerah }\end{array}$ & $\begin{array}{c}\text { Retribusi } \\
\text { Daerah }\end{array}$ & $\begin{array}{c}\text { Hasil Pengelolaan } \\
\text { Kekayaan Daerah } \\
\text { Yang Dipisahkan }\end{array}$ & $\begin{array}{c}\text { Lain-Lain PAD } \\
\text { Yang Sah }\end{array}$ \\
\hline 2014 & $54,77 \%$ & $15,36 \%$ & $2,50 \%$ & $27,37 \%$ \\
\hline 2015 & $59,79 \%$ & $15,17 \%$ & $1,17 \%$ & $23,86 \%$ \\
\hline 2016 & $65,43 \%$ & $18,12 \%$ & $1,11 \%$ & $15,34 \%$ \\
\hline 2017 & $57,74 \%$ & $13,41 \%$ & $0,98 \%$ & $27,87 \%$ \\
\hline 2018 & $70,72 \%$ & $13,61 \%$ & $2,35 \%$ & $13,33 \%$ \\
\hline
\end{tabular}

Sumber: data diolah (2019)

a. Penerimaan PAD dari Pajak Daerah tahun 2014-2018 mengalami kenaikan kontribusi walau di 3 tahun terakhir mengalami kenaikan ditahun 2017 mengalami penurunan kontribusi. Ditahun 2014 kontribusi pajak daerah ialah sebesar 54,77\% dan ditahun 2015 meningkat sebesar 5,02\% menjadi 59,79\%. Kemudian kembali meningkat ditahun 2016 sebesar 5,64\% dan penerimaan menjadi 65,43\% lalu di tahun 2017 mengalami penurunan sebesar 7,69\% menjadi sebesar 57,74 \%. Ditahun 2018 penerimaan kembali mengalami peningkatan sebesar $12,98 \%$ menjadi sebesar 70,72\%.

b. Penerimaan PAD dari Retribusi Daerah tahun 2014-2018 mengalami penurunan kontribusi walau mengalami penurunan ditahun 2016 mengalami kenaikan kontribusi. Ditahun 2014 kontribusi retribusi daerah ialah sebesar 15,36\% dan ditahun 2015 mengalami penurunan sebesar 0,19\% menjadi 15,17\%. Kemudian meningkat ditahun 2016 sebesar 2,95\% dan penerimaan menjadi 18,12\% lalu di tahun 2017 mengalami penurunan kembali sebesar 4,71\% menjadi sebesar 13,41\%. Ditahun 2018 penerimaan kembali mengalami peningkatan sebesar 0,20\% menjadi sebesar 13,61\%.

c. Penerimaan PAD dari Hasil Pengelolaan Kekayaan Daerah Yang Dipisahkan tahun 2014-2018 mengalami penurunan kontribusi walau di 4 tahun terakhir mengalami penurunan ditahun 2018 mengalami kenaikan kontribusi. Ditahun 2014 kontribusi Hasil Pengelolaan Kekayaan Daerah Yang Dipisahkan ialah sebesar 2,50\% dan ditahun 2015 mengalami penurunan sebesar 1,33\% menjadi 1,17\%. Kemudian kembali menurun ditahun 2016 sebesar 0,06\% 


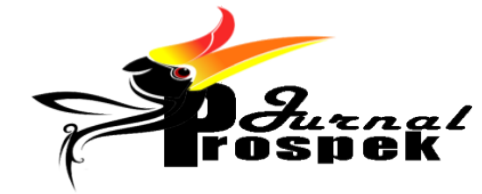

http://e-journals.unmul.ac.id/index.php/jpe

Jurnal Prospek : Pendidikan Ilmu Sosial dan Ekonomi

Volume 3 No 1 Juli 2021

E-ISSN 2721-0855

dan penerimaan menjadi 1,11\% lalu di tahun 2017 mengalami penurunan sebesar 0,13\% menjadi sebesar 0,98\%. Ditahun 2018 penerimaan mengalami peningkatan sebesar 1,37\% menjadi sebesar $2,35 \%$.

d. Penerimaan PAD dari Lain-Lain PAD Yang Sah tahun 2014-2018 mengalami penurunan kontribusi walau mengalami penurunan ditahun 2017 mengalami kenaikan kontribusi. Ditahun 2014 kontribusi Lain-Lain PAD Yang Sah ialah sebesar 27,37\% dan ditahun 2015 mengalami penurunan sebesar 3,51\% menjadi 23,86\%. Kemudian menurun kembali ditahun 2016 sebesar 8,52\% dan

e. Penerimaan menjadi 15,34\% lalu di tahun 2017 mengalami kenaikan sebesar 12,53\% menjadi sebesar 27,87\%. Ditahun 2018 penerimaan kembali mengalami penurunan sebesar $14,54 \%$ menjadi sebesar $13,33 \%$.

\section{PEMBAHASAN}

Besar atau kecilnya kontribusi realisasi pajak daerah juga dipengaruhi dari penerimaan pajak daerah itu sendiri. Berdasarkan Pada Undang-Undang Nomor 28 Tahun 2009 Tentang Pajak Daerah dan Retribusi Daerah, maka Pemerintah Daerah Bersama dengan DPRD Kota Samarinda menerbitkan Peraturan Daerah Kota Samarinda Nomor 04 Tahun 2011 Tentang Pajak Daerah dimana terdapat 11 jenis pajak daerah yang ada, yaitu Pajak Hotel, Pajak Restoran, Pajak Hiburan, Pajak Reklame, Pajak Penerangan Jalan, Pajak Parkir, Pajak Air Tanah, Pajak Sarang Burung Walet, Pajak Mineral Bukan Logam dan Batuan, Pajak Bumi dan Bangunan Perdesaan dan Perkotaan, Bea Perolehan Hak Atas Tanah dan Bangunan .

Berikut ini adalah kontribusi realisasi masing-masing pajak daerah terhadap realisasi PAD mulai tahun 2014 sampai tahun 2018. 


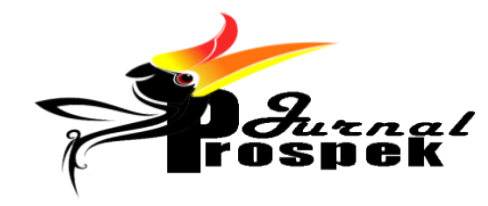

http://e-journals.unmul.ac.id/index.php/jpe Jurnal Prospek : Pendidikan Ilmu Sosial dan Ekonomi Volume 3 No 1 Juli 2021

E-ISSN 2721-0855

\section{Tabel 5. Kontribusi Realisasi Pajak Daerah Terhadap Realisasi PAD di Kota} Samarinda Tahun 2014-2018

\begin{tabular}{clcccccc}
\hline \multirow{2}{*}{ No } & \multirow{2}{*}{ Pajak Daerah } & \multicolumn{7}{c}{ Kontribusi Pajak Daerah Terhadap PAD } & \multirow{2}{*}{$\begin{array}{c}\text { Rata- } \\
\text { Rata }\end{array}$} \\
\cline { 3 - 7 } & 2014 & 2015 & 2016 & 2017 & 2018 & $5,32 \%$ \\
\hline 1 & Pajak Hotel & $4,16 \%$ & $5,05 \%$ & $6,63 \%$ & $4,98 \%$ & $5,79 \%$ & 5,30 \\
\hline 2 & Pajak Restoran & $6,43 \%$ & $8,37 \%$ & $10,34 \%$ & $8,69 \%$ & $11,44 \%$ & $9,05 \%$ \\
\hline 3 & Pajak Hiburan & $3,43 \%$ & $3,75 \%$ & $4,38 \%$ & $3,67 \%$ & $4,40 \%$ & $3,93 \%$ \\
\hline 4 & Pajak Reklame & $1,59 \%$ & $1,84 \%$ & $1,80 \%$ & $1,32 \%$ & $1,44 \%$ & $1,60 \%$ \\
\hline 5 & $\begin{array}{l}\text { Pajak } \\
\text { Penerangan }\end{array}$ & $15,89 \%$ & $20,52 \%$ & $23,09 \%$ & $19,16 \%$ & $21,34 \%$ & $20,00 \%$ \\
\hline 6 & Pajak Parkir & $1,09 \%$ & $1,49 \%$ & $2,03 \%$ & $1,50 \%$ & $1,80 \%$ & $1,58 \%$ \\
\hline 7 & $\begin{array}{l}\text { Pajak Air } \\
\text { Tanah }\end{array}$ & $0,01 \%$ & $0,01 \%$ & $0,01 \%$ & $0,01 \%$ & $0,02 \%$ & $0,01 \%$ \\
\hline 8 & $\begin{array}{l}\text { Pajak Sarang } \\
\text { Burung Walet }\end{array}$ & $0,00 \%$ & $0,00 \%$ & $0,01 \%$ & $0,00 \%$ & $0,00 \%$ & $0,00 \%$ \\
\hline $\begin{array}{l}\text { Pajak Mineral } \\
9\end{array}$ & $\begin{array}{l}\text { Bukian Logam } \\
\text { dan Batuan }\end{array}$ & $0,15 \%$ & $0,03 \%$ & $0,01 \%$ & $0,00 \%$ & $0,02 \%$ & $0,04 \%$ \\
\hline 10 & Pajak BBPP & $8,59 \%$ & $8,17 \%$ & $8,71 \%$ & $7,49 \%$ & $7,12 \%$ & $8,02 \%$ \\
\hline 11 & Pajak BPHTB & $13,42 \%$ & $10,56 \%$ & $8,42 \%$ & $10,94 \%$ & $17,33 \%$ & $12,13 \%$ \\
\hline
\end{tabular}

Sumber: Data diolah (2019)

1. Pajak Hotel

Penerimaan PAD dari pajak hotel tahun 2014 memasuki kategori sangat baik dan mengalami kategori sangat baik ditahun 2015, 2016, 2017, dan 2018 namun walau di 3 tahun terakhir memasuki kategori sangat baik ditahun 2017 mengalami penurunan kontribusi. Ditahun 2014 kontribusi pajak hotel ialah sebesar 4,16\% dan ditahun 2015 meningkat sebesar 0,89\% menjadi 5,05\% yang termasuk dalam kategori sangat baik. Meningkat kembali ditahun 2016 sebesar 1,58\% dan penerimaan menjadi 6,63\% dan termasuk dalam kategori sangat baik. Lalu di tahun 2017 mengalami penurunan sebesar 1,65\% menjadi sebesar 4,98 \% namun tetap termasuk kedalam kategori sangat baik. Ditahun 2018 penerimaan kembali memasuki kategori sangat baik karena mengalami peningkatan sebesar 0,81\% menjadi sebesar 5,79\%.

2. Pajak Restoran

Penerimaan PAD dari pajak restoran memasuki kategori sangat baik dari tahun 2014 2018 namun mengalami penurunan kontribusi di tahun 2017. pada tahun 2014 penerimaan 


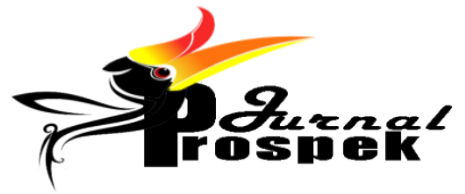

http://e-journals.unmul.ac.id/index.php/jpe

Jurnal Prospek : Pendidikan Ilmu Sosial dan Ekonomi

Volume 3 No 1 Juli 2021

E-ISSN 2721-0855

sebesar 6,43\%, pada tahun 2015 penerimaan pajak restoran naik sebesar 8,37\% yang menunjukkan peningkatan dari tahun sebelumnya sebesar 1,94\%, dan ditahun 2016 meningkat kembali sebesar 1,97\% yang kemudian penerimaan menjadi sebesar 10,34\%. Namun pada tahun 2017 mengalami penurunan sebesar 1,65\% menjadi sebesar 8,69\%. Ditahun 2018 meningkat kembali sebesar 2,75\% yang kemudian penerimaan menjadi sebesar $11,44 \%$

\section{Pajak Hiburan}

Penerimaan PAD dari pajak hiburan dalam kurun waktu lima tahun terakhir mengalami peningkatan yang artinya dapat dikatakan baik dalam memberikan kontribusi karena setiap tahun realisasi yang dicapai dapat melampaui target yang telah ditetapkan. Dan pada tahun 2016 dan 2018 memasuki kategori kontribusi yang sangat baik. Pada tahun 2014 kontribusi pajak hiburan kota Samarinda dikategorikan baik yaitu sebesar 3,43\%, pada tahun 2015 penerimaan pajak hiburan mengalami peningkatan sebesar 0,32\% dari tahun sebelumnya menjadi 3,75\% , dan ditahun 2016 kontribusi pajak hiburan kota Samarinda sangat baik dengan presentase sebesar 4,38\% yang menunjukkan kenaikan sebesar 0,63\% dari tahun sebelumnya. namun di tahun 2017 mengalami penurunan sebesar 0,71\% menjadi sebesar 3,67\% namun masih dalam kategori baik dan kembali meningkat di tahun 2018 kontribusi pajak hiburan kota Samarinda sangat baik dengan presentase sebesar 4,40\% yang menunjukan kenaikan sebesar $0,70 \%$.

4. Pajak Reklame

Penerimaan PAD dari pajak reklame walau selalu mengalami penaikan dan penurunan namun pajak reklame masih saja memasuki kategori kurang baik dalam 5 tahun terakhir. Pada tahun 2014 penerimaan pajak reklame ialah sebesar 1,59\% lalu di tahun 2015 mengalami kenaikan sebesar 0,25\% menjadi 1,84\% dan masih memasuki kategori kurang baik. Pada tahun 2016 mengalami penurunan sebesar 0,04\% menjadi 1,80\% namun masih memasuki kategori kurang baik, dan mengalami penurunan kembali pada tahun 2017 sebesar 0,49\% menjadi sebesar 1,31\% tapi masih memasuki kategori kurang baik. Begitupula di tahun 2018 mengalami kenaikan sebesar 0,13\% menjadi 1,44\% dan masih dalam kategori kurang baik. 


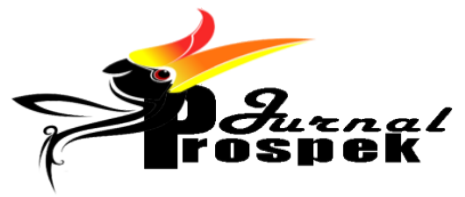

http://e-journals.unmul.ac.id/index.php/jpe Jurnal Prospek : Pendidikan Ilmu Sosial dan Ekonomi

Volume 3 No 1 Juli 2021

E-ISSN 2721-0855

5. Pajak Penerangan Jalan

Penerimaan pajak penerangan jalan memasuki kategori sangat baik dalam kurun waktu 5 tahun terakhir. Pada tahun 2014 penerimaan pajak penerangan jalan sebesar 15,89\% dan ditahun 2015 mengalami peningkatan sebesar 4,63\% menjadi 20,52\% dan mengalami peningkatan kembali ditahun 2016 sebesar 2,57\% dan penerimaan menjadi sebesar 23,09\% dan ditahun 2017 mengalami penurunan kembali sebesar 3,94\% menjadi 19,16 \% namun masih dalam kategori sangat baik. Pada tahun 2018 mengalami peningkatan kembali sebesar 2,18\% menjadi 21,34. Besarnya pajak yang didapatkan disektor ini disebabkan karena dasar pemungutan pajak penerangan jalan sangat jelas dan pasti.

6. Pajak Parkir

Penerimaan PAD dari pajak parkir dari tahun 2014 - 2016 cukup mengalami peningkatan yang sedikit signifikan walaupun ditahun 2017 mengalami penurunan yang sangat drastis. Pada tahun 2014 penerimaan pajak parkir ialah sebesar 1,09 \% dan masuk ke dalam kategori kurang baik. Dan di tahun 2015 mengalami kenaikan sebesar 0,40\% menjadi 1,49\% dan masuk ke kategori kurang baik. Dan di tahun 2016 mengalami kenaikan kembali sebesar 0,53\% menjadi 2,02\% namun dalam kategori cukup baik. Dan di tahun 2017 mengalami penurunan yang menjadikan kategori kurang baik yaitu mengalami penurunan sebesar 0,52\% menjadi 1,50\% namun ditahun 2018 mengalami kenaikan sebesar $0,30 \%$ tetap menjadi kategori kurang baik yaitu menjadi sebesar 1,80\%.

7. Pajak Air Tanah

Penerimaan PAD dari Pajak Air Tanah belum maksimal dan potensinya belum dikembangkan ditahun 2014-2018 tidak ada yang mampu naik secara signifikan. di 5 tahun terakhir ini kategori Pajak Air Tanah masih berada di kategori tidak baik.

Hal ini disebabkan karena sebagian atau seluruh masyarakat Samarinda saat ini sudah banyak yang lebih memilih menggunakan air PDAM dibandingkan menggunakan air galian yang dimiliki sendiri atau digali dari bawah tanah.

8. Pajak Sarang Burung Walet

Penerimaan PAD dari Pajak Sarang Burung Walet Belum mengalami penaikan yang sangat signifikan karena dilima tahun terakhir tahun 2014-2018 Pajak Sarang Burung Walet masih berada dalam kategori Tidak Baik. Di tahun 2014-2016 dari hasil pajak yang 


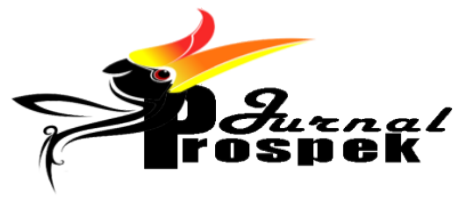

http://e-journals.unmul.ac.id/index.php/jpe

Jurnal Prospek : Pendidikan Ilmu Sosial dan Ekonomi

Volume 3 No 1 Juli 2021

E-ISSN 2721-0855

dihasilkan mengalami sedikit penaikan walau tidak secara signifikan atau drastis. Namun, di tahun 2017-2018 dari pajak sarang burung walet mengalami penurunan kembali sebesar 0,01\% dari tahun 2016.

Hal ini disebabkan karena Bapenda hanya bisa menarik pajak dari usaha-usaha yang berizin, pajak sarang burung walet memang belum dijadikan sebagai sumber yang unggul dan belum ditekankan dalam pemungutannya karena memang belum memiliki potensial. Sehingga, pajak sarang burung walet dalam memberikan kontribusinya terhadap PAD belum menunjukan hasil yang baik.

\section{Pajak Mineral Bukan Logam dan Batuan}

Penerimaan PAD dari Pajak Mineral Bukan Logam dan Batuan dari 4 tahun terakhir mengalami penurunan yang sangat besar dari setiap tahunnya pada tahun 2014 penerimaan sebesar 0,15\% lalu ditahun 2015 mengalami penurunan yang sangat drastis sebesar 0,12\% menjadi 0,03\% lalu kembali lagi ditahun 2016-2107 turun menerus sebesar 0,01\% disetiap tahunnya menyebabkan ditahun 2017 hanya 0,00\% dan kemudian di tahu 2018 mnegalami kenaikan sebesar 0,02\% dari penerimaan PAD yang diterima.

10. Pajak Bumi dan Bangunan Perdesaan dan Perkotaan

Penerimaan PAD dari Pajak Bumi dan Bangunan Perdesaan dan Perkotaan di tahun 20134-2018 selalu berada dikategori sangat baik , pada tahun 2014 sebesar 8,59\% dan ditahun 2015 mengalami penurunan sebesar 0,43\% menjadi 8,17\% namun ditahun 2016 mengalami kenaikan sebesar 0,54\% menjadi 8,71\% dan ditahun 2017 kembali mengalami penurunan sebesar 1,22\% menjadi 7,49\% dari tahun sebelumnya. Namun kembali lagi di tahun 2018 Pajak bumi dan bangunan perdesaan dan perkotaan kembali mengalami penurunan sebesar $0,37 \%$ menjadi $7,12 \%$ walaupun di lima tahun terakhir selalu mengalami kenaikan atau penurunan pajak bumi dan bangunan perdesaan dan perkotaan masih dalam kategori sangat baik.

11. Bea Perolehan Hak Atas Tanah dan Bangunan

Penerimaan PAD dari Bea Perolehan Hak Atas Tanah dan Bangunan di tahun 2014-2016 mengalami penurunan disetiap tahun, ditahun 2014 ialah sebesar 13,42\% dan ditahun 2015 mengalami penurunan sebesar 2,86\% menjadi 10,56\% kemudian ditahun 2016 mengalami penurunan kembali sebesar 2,14\% menjadi 8,42\% namun ditahun 2017 mengalami kenaikan sebesar 2,51\% menjadi 10,94\% dan ditahun 2018 kembali meningkat sebesar 


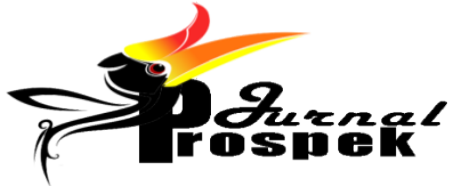

http://e-journals.unmul.ac.id/index.php/jpe

Jurnal Prospek : Pendidikan Ilmu Sosial dan Ekonomi

Volume 3 No 1 Juli 2021

E-ISSN 2721-0855

6,39\% menjadi 17,33\%. namun walaupun selalu mengalami penurunan dan peningkatan

dalam 5 tahun terakhir PAD dari Bea Perolehan Hak Atas Tanah dan Bangunan masih dalam kategori Sangat Baik

\section{KESIMPULAN}

Berdasarkan hasil penelitian Tingkat Kontribusi pada tahun 2014 - 2018 komponenkomponen pajak memberikan kontribusi yang bervariasi ada yang memang kontribusinya sangat signifikan dan ada yang belum memiliki kontribusi yang maksimal. Penerimaan pajak daerah secara representatif sudah menunjukkan kenaikan yang signifikan, maka kontribusinya terhadap pendapatan asli daerah sudah mencapai target realisasi pajak daerah. Walaupun dalam kurun waktu 5 tahun terakhir mengalami peningkatan tetapi ada nilai kontribusi yang sangat kecil pendapatannya terhadap pendapatan asli daerah. seperti pajak burung walet, mineral bukan logam, dan air bawah tanah. Ini dikarenakan target realisasinya memang kecil dan tidak memengaruhi, karena sedikit. Pajak daerah yang memberikan kontribusi terbesar kepada PAD adalah Pajak Penerangan Jalan dengan rata-rata kontribusi selama tahun 2014 hingga 2018 adalah 20,00\%. 


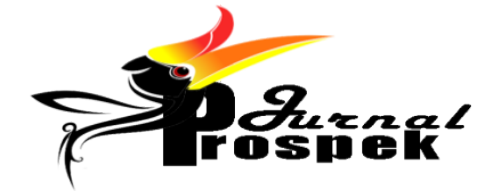

http://e-journals.unmul.ac.id/index.php/jpe

Jurnal Prospek : Pendidikan Ilmu Sosial dan Ekonomi

Volume 3 No 1 Juli 2021

E-ISSN 2721-0855

DAFTAR PUSTAKA

Anonim. Peraturan Daerah Kota Samarinda No. 04 Tahun 2011 Tentang Pajak Daerah

Anonim. Undang-Undang Republik Indonesia Nomor 28 Tahun 2009 Tentang Pajak Daerah dan Retribusi Daerah

Halim, Abdul. (2007). Akuntansi Sektor Publik Keuangan Daerah, Yogyakarta:

Salemba Empat

Juri, Mat. (2012). Analisis Kontribusi Pajak Daerah dan Retribusi Daerah Terhadap Pendapatan Asli Daerah (PAD) Kota Samarinda, Karya Ilmiah, Samarinda

Mardiasmo. (2011). Perpajakan Edisi Revisi, Yogyakarta

Mike. (2012). Analisis Kontribusi Jenis-Jenis Pajak Daerah dan Jenis-Jenis Retribusi Daerah Terhadap Pendapatan Asli Daerah (PAD) Kabupaten Kutai Barat Tahun 2006 Sampai Dengan Tahun 2011, Tugas Akhir, Samarinda

Nugroho, Thoriq Ilham. (2017). Analisis Kontribusi dan Efektivitas Pajak Daerah dan Retribusi Daerah Terhadap Pendapatan Asli Daerah (PAD) Kota Samarinda Periode 2012-2016, Tugas Akhir, Samarinda

Utami, Ariska Dwi. (2018). Analisis Kontribusi Pajak Daerah Terhadap Pendapatan Asli Daerah (PAD) Kota Samarinda Periode 2013-2017,Tugas Akhir, Samarinda.

Siahaan, M.P. (2009). Pajak Daerah dan Retribusi Daerah. Edisi Revisi

www.pajak.go.id. Pengertian, Fungsi, dan Jenis Pajak.

http://www.ilmusiana.com/2015/11/6-tujuan-pelaksaan-otonomi-daerah.html 